tuottoja 17 315,60 euroa. Yhteensä Virittäjän tuotot olivat 61368,38 euroa. Menoja kertyi 69 187,40 euroa. Suurimmat kulut aiheutuivat painatuksesta ja postituksesta (20 473,78 euroa) sekä henkilöstökuluista (37 631,78 euroa). Virittäjän tulos vuodelta 2016 on 7 819,02 euroa alijäämäinen.

Seuran tuotot koostuivat pääosin jäsenmaksuista, jotka olivat 2 814,oo euroa. Seuran varsinaisen toiminnan kulut olivat 4 359,67 euroa, ja ne koostuivat pääosin jäsenkokousten järjestämisestä ja kirjanpidosta. Sijoitus- ja rahoitustoiminnan tulos oli 11252,78 euroa, ja rahastoihin tuotoista siirrettiin 10729,50 euroa. Seu- ran tulos vuodelta 2016 on 1022,39 euroa alijäämäinen.

Kotikielen Seuran ja Virittäjän vuoden 2016 yhteinen tilinpäätös osoittaa tuottoja 75 663,21 euroa, kuluja 73 775,12 euroa ja rahastoille siirrettävää tuottoa 10729,50 euroa. Alijäämäksi muodostuu 8 841,41 euroa.

Helsingissä 27. helmikuuta 2017

Pilvi Heinonen

Kotikielen Seuran sihteeri etunimi.sukunimi@helsinki.fi

\title{
Viranomaisviestinnästä kahdella kielellä
}

Eveliina Tolvanen: Myndighetskommunikation på två språk. Pensionstexer på svenska och finska i Finland och Sverige $i$ ett systemisk-funktionellt perspektiv. Turun yliopiston julkaisuja. Annales Universitatis Turkuensis B 425. Humaniora. Turku: Turun yliopisto 2016. Johdanto 84 s., artikkelit 124 s. ISBN 978-951-29-6663-9.

Eveliina Tolvanen väitteli Turun yliopistossa 9. joulukuuta 2016 kahdella kielellä toteutetusta viranomaisviestinnästä. Tutkimuksen kohteena ovat eläkeaiheiset informoivat ja neuvovat verkkotekstit. Tutkimuksesta erityisen tekee se, että aineiston tekstit edustavat neljää varieteettia: ruotsinruotsia, suomenruotsia, suomensuomea ja ruotsinsuomea. Kyseessä on artikkeliväitöskirja, jossa on yhteenveto- osan lisäksi viisi osatutkimusta. Niissä tarkastellaan samaa aineistoa eri näkökulmista. Lisäksi yhteenveto-osaan sisältyy suppea tekstien kirjoitusprosessia koskeva kyselytutkimus, johon on saatu yhteensä seitsemän vastausta. Artikkeleista yksi on suomenkielinen, ja loput neljä on kirjoitettu ruotsiksi. Tolvanen on artikkeleiden ainoa tekijä, ja ne on julkaistu neljän vuoden aikana.

Tutkimuksen tavoitteena oli selvittää, minkälaisia yhtäläisyyksiä ja eroja suomalaisten ja ruotsalaisten sekä suomenettä ruotsinkielisten informoivien ja neuvovien eläkeaiheisten verkkotekstien välillä on ja mistä mahdolliset erot johtuvat. Tutkimus jakautuu edelleen viiteen tutkimuskysymykseen, joita kutakin tarkastellaan omissa artikkeleissaan. Artikkeleissa 
käsitellään tekstien verkkotekstiluonnetta, nominaalirakenteita, auktoriteetin esittämistä, lukijan puhuttelua sekä persoonattomia rakenteita. Tekstien välisiä eroja pohditaan suhteessa kulttuuriympäristöön ja kielen asemaan yhteiskunnassa.

\section{Aineisto}

Tutkimuksen aineisto on kiinnostava, sillä se tarjoaa mahdollisuuden verrata suomenruotsia Ruotsissa puhuttavaan ruotsiin ja vastaavasti ruotsinsuomea Suomessa käytettävään suomen kieleen. Aineiston valinnan taustalla onkin ajatus siitä, että ruotsi ja suomi ovat plurisentrisiä kieliä, joilla on erilaisia normeja eri maissa. Tutkimuksessa siis vertaillaan systemaattisesti kahden maan viranomaistekstejä ja pohditaan syitä yhtäläisyyksiin ja eroihin. Suomen ja Ruotsin vertailu on luontevaa ja mahdollista, koska yhteiskuntarakenteet ovat riittävän samantyyppiset. Selkein ero on toisen kielen statuksessa: ruotsin kielellä on Suomessa selvästi erilainen asema kuin suomen kielellä Ruotsissa. Myös eläkejärjestelmät ovat erilaiset, mikä vaikuttaa tekstien mahdollisiin lukijoihin: Ruotsissa eläkekruununsa voi sijoittaa itse jo työuransa alusta alkaen, joten eläketeksteillä voi olla melko nuoriakin lukijoita. Väitöskirjassa tehdyt vertailut ovat hyvin perusteltuja, ja ne johtavat mielenkiintoisiin tuloksiin.

Tutkitut tekstit on poimittu Suomen Kelan ja Ruotsin Eläkeviraston (Pensionsmyndigheten) verkkosivuilta huhti-elokuussa vuonna 2012. Tekstit olivat avoimesti saatavissa olevia verkkotekstejä. Kelan osalta mukana ovat eläkeläisille ja yleisesti henkilöasiakkaille suunnatut tekstit. Ruotsin Eläkeviraston sivuilta on valittu tekstit, jotka käsittelevät eläkkeelle siirtymistä ja eläkejärjestelmää yleensä. Eläkeviraston sivuilta tutkimukseen valitut suomenkieliset tekstit kattavat osion Suomeksi, joka puolestaan on sijoitettu otsikon International alle. Kaikkiaan aineistossa on 407 tekstiä ja 133900 sanaa. Keskimääräinen sanamäärä teksteissä vaihtelee vähän yli sadasta sanasta (ruotsinsuomalaiset tekstit) aina 415 sanaan (ruotsinruotsalaiset tekstit). Suomessa julkaistuissa teksteissä on kielestä riippumatta käytännössä sama sisältö, kun taas Ruotsissa julkaistujen erikielisten tekstien välillä on suuria eroja; suomenkielinen teksti on lähinnä tiivistelmä useammasta ruotsinkielisestä tekstistä, ja sen yhteydessä on aina vastaava teksti myös ruotsiksi.

\section{Teoreettinen lähtökohta}

Menetelmällisesti tutkimus edustaa erikoisalojen tekstien tutkimusta, jolla on etenkin ruotsin kielen osalta pitkät perinteet, ja tarjolla on runsaasti vertailuaineistoa. Varsinkin tiedotus- ja ohjetekstejä on tutkittu paljon jo aiemmin. Teoreettisena viitekehyksenä tutkimuksessa on systeemis-funktionaalinen kielentutkimus, johon kielen piirteiden vertailu perustuu. Tutkija itse käyttää nimitystä SFLvaikutteinen lingvistinen tekstianalyysi (SFL-inspirerad lingvistisk textanalys), mikä on osuva kuvaus artikkelien sisältämistä sekä määrällisistä että laadullisista analyyseistä. Kielellisten piirteiden analyysin ytimessä on jako ideationaalisiin ja interpersonaalisiin piirteisiin. Ideationaalisista piirteistä tarkastelussa ovat kieliopillinen metafora ja ergatiiviset roolit, interpersonaalisista piirteistä puolestaan interaktiivinen aukko (interaktionell lucka) ja interaktiivinen inkongruenssi (interaktionell inkongruens). Esittelen näitä käsitteitä tarkemmin artikkelien kuvauksen yhteydessä.

Kuten tutkimusasetelmasta ilmenee, väitöskirjan lähtökohdat ovat erittäin kunnianhimoiset: mukana on kaksi maata, kaksi kulttuuria, kaksi eläkejärjestelmää, kaksi kieltä ja edelleen kaksi kieliopillista termistöä, ruotsin ja suomen 
kielen. Tutkimuksen aihe on ajankohtainen ja yhteiskunnallisesti tärkeä kahdestakin näkökulmasta. Toisaalta perinteinen muuttoliike Ruotsin ja Suomen välillä on jo pitkään johtanut siihen, että ikääntyvät muuttajat ovat päätyneet toisen maan eläkejärjestelmän piiriin. Toisaalta yhteiskunnan yleisen ikääntymiskehityksen myötä eläkeaiheisten tekstien lukijoita on paljon, joten niiden kieleen on tärkeää kiinnittää huomiota - myös niin sanotun toisen kielen osalta. Lisäksi kysymys siitä, miten viranomaiset saavat viestinsä perille yksittäisille ihmisille parhaalla mahdollisella tavalla, on aina ajankohtainen. Tästä näkökulmasta Tolvasen tutkimuksella on myös ideologisia ja kielipoliittisia ulottuvuuksia, ja kielitietoisuus, kielelliset oikeudet ja kielenhuolto nousevat olennaisiksi tuloksia selittäviksi tekijöiksi. Varsinainen analyysi painottuu kuitenkin vahvasti lingvistiseen tekstianalyysiin. Tutkimus ei vertailuasetelmasta huolimatta ole perinteinen kontrastiivinen analyysi, vaan vertailu on kielikohtaista (esim. ruotsinruotsi vs. suomenruotsi). Kääntämistä ei tutkimuksessa myöskään nosteta erityisen tarkastelun kohteeksi. Nämä rajaukset ovat tutkimusasetelman laajuuteen nähden järkeviä, ja Tolvanen selviää tutkimustehtävästään kokonaisuudessaan hyvin.

\section{Väitöskirjan osatutkimukset}

Väitöskirjan ensimmäinen osa-artikkeli (Tolvanen 2013) on julkaistu VAKKI-sarjassa, ja se on yleiskatsaus siihen, miten tarkastellut eläkeaiheiset tekstit on graafisesti sijoitettu verkkosivuille ja minkälaisia visuaalisia ja interaktiivisia piirteitä niihin liittyy. Artikkeli toimii lähinnä tekstien esiintymiskontekstin kuvauksena, ja se auttaakin lukijaa ymmärtämään paremmin, minkälaisista teksteistä on kyse. Artikkelin otsikossa mainitaan kontrastiivinen näkökulma (kontrastivt perspektiv), jota ei kuitenkaan pohdita sen enempää artikkelissa eikä muuallakaan väitöskirjassa. Artikkelissa osoitetaan, että aineiston tekstien välillä on eroja, ja pohditaan niiden syitä. Tällaisiksi esitetään muun muassa kulttuuriin liittyvät tekijät sekä käytetyn kielen status (kansalliskieli kuten ruotsi Suomessa vs. vähemmistökieli kuten suomi Ruotsissa). Pohdinta ei mene kovin syvälle, ja artikkelin lyhyys johtaa myös jossain määrin omintakeisiin tulkintoihin. Esimerkiksi periaate vastaanottajan huomioimisesta tekstisisältöjen valinnassa (innehållslig mottagaranpassning) on rajattu pelkästään tekstien löydettävyyteen, vaikka periaatteen keskeisin ajatus on olennaisen sisällön valitseminen aiotulle vastaanottajaryhmälle. Analyysin tulos on, että Suomessa julkaistut tekstit ovat teknisesti verkkoon sovitettuja, informaatio on tekstipohjaista ja että suomen- ja ruotsinkieliset tekstit ovat käytännössä samansisältöisiä. Ruotsissa julkaistut tekstit ovat puolestaan keskenään hyvin erilaisia: ruotsinruotsalaisissa teksteissä on enemmän visuaalisia ja interaktiivisia elementtejä, kun taas ruotsinsuomalaiset tekstit ovat lähinnä ruotsinkielisten tekstien lyhennelmiä ja lisäksi niiden yhteydessä on aina myös vastaava ruotsinkielinen versio. Tämä artikkeli on ainoa, jossa selvästi huomioidaan aineiston verkkotekstiluonne.

Väitöskirjan toinen artikkeli on julkaistu Folkmålsstudier-lehdessä (Tolvanen 2014b). Sen aiheena on kompleksisten substantiivilausekkeiden käyttö ruotsinkielisissä teksteissä (suomenruotsissa ja ruotsinruotsissa). Tarkastelussa ovat NP:t, joihin liittyy genetiiviattribuutti, prepositioattribuutti tai rinnastus (esim. "Henkilötietojen muutoksista sekä muuttuneesta tilinumerosta voit ilmoittaa - -"). Mutkikkaita NP:itä voidaankin pitää yhtenä viranomaistekstien kielenhuollon kestoaiheista (esim. Reuter 2006). Artikkeli on perusteellinen ja hyvin kirjoitettu, ja siinä pohditaan keskeisten käsitteiden määrittelyjä, muun muassa substantiivi- 
lausekkeen ja kieliopillisen metaforan (ks. esim. Halliday 1998: 192) osalta. Artikkelissa olisi kuitenkin voinut nostaa selkeämmin esille, mikä tuloksissa on uutta tietoa verrattuna muun muassa Lassuksen (2006) tutkimukseen. Suomen kielen vaikutusta suomenruotsiin ei käsitellä systemaattisesti, joten artikkelista ei täysin selviä, miten tutkija näkee mahdolliset syy-seuraussuhteet. Tutkimuksen tulokset tukevat aiempia havaintoja, joiden mukaan suomenruotsalaiset tekstit ovat staattisempia ja leksikaalisesti tiheämpiä kuin ruotsinruotsalaiset tekstit. Ilmiön taustalla oleviin syihin artikkelissa ei kuitenkaan päästä kovin syvälle. Lisäksi artikkelin johtopäätöksenä esitetään, että substantiivilausekkeiden käyttö antaa vaikutelman erikoiskielisyydestä. Yleensä vastaava vaikutelma syntyy runsaasta termien käytöstä, mutta artikkelissa ei kuitenkaan pohdita, riittääkö vaikutelmaan pelkkä substantiivilausekkeiden käyttö vai edellyttääkö se, että kyseiset lausekkeet ovat termejä. Yhteenvedossa pohditaan tämän artikkelin osalta, kenen näkökulmasta tekstit on kirjoitettu, viranomaisen vai lukijan. Tätä lukijan näkökulmaa olisikin ollut väitöskirjassa hyvä tarkastella myös systemaattisemmin.

Väitöskirjan kolmas artikkeli on julkaistu Språk och stil -lehdessä (Tolvanen 2014a), ja siinä pohditaan, miten viranomaisen ja kansalaisen suhde ilmenee teksteissä. Tämä niin sanottu interpersonaalinen analyysi kohdistuu ruotsinkielisiin teksteihin, ja sen tarkoituksena on selvittää, miten viranomainen ja oletettu lukija konstruoidaan teksteihin. Analyysi kohteena ovat projisoidut roolit (projicerade roller), joita tutkitaan sanastollis-kieliopillisten valintojen (esim. Kela, me, eläkkeensaaja, sinä) kautta, sekä ergatiiviset roolit. Systeemis-funktionaalisen kielentutkimuksen mukaisessa ergatiivisuuden tarkastelussa on kyse osallistujaroolien analyysista - erityisesti siitä, vaikuttaako lauseen osallistuja muihin osal- listujiin vai ei. (Halliday \& Matthiessen 2004: 287-288). Tutkimus on tehty kypsällä otteella ja valinnat on perusteltu hyvin. Tulokset osoittavat, että viranomainen on teksteissä vähemmän näkyvä kuin oletettu lukija. Suomenruotsalaisissa teksteissä viranomaiset esitetään tahona, joka myöntää ja maksaa eläkkeitä, kun taas ruotsinruotsalaiset viranomaiset laskevat (beräknar) eläkkeitä. Näin Suomessa ja Ruotsissa korostetaan viranomaisen toiminnan eri puolia. Ruotsinruotsalainen teksti vastaakin kysymykseen, "kuinka paljon eläkettä minä saan", kun taas suomenruotsalainen teksti vastaa kysymykseen, "mitä minun täytyy tehdä, että saan eläkettä". Tulokset vahvistavat aiemman tutkimuksen havaintoa, että auktoriteettia ja etäisyyttä ilmaistaan selvemmin suomenruotsalaisissa teksteissä. Lisäksi artikkeliin sisältyy kiinnostava pohdinta asymmetrian merkityksestä eli siitä, ilmaistaanko auktoriteettia eksplisiittisesti vai implisiittisesti. Oivaltava havainto on, että vaikka auktoriteetti piilotetaan tekstissä, se ei kuitenkaan katoa mihinkään. Lukijan näkökulma olisi voitu artikkelissa huomioida systemaattiseemmin.

Väitöskirjan neljäs osatutkimus on kirjoitettu suomeksi ja julkaistu Virittäjässä (Tolvanen 2016a). Artikkeli jatkaa interpersonaalista analyysiä ja keskittyy lukijan puhutteluun. Aineisto koostuu pääasiassa suomenkielisistä teksteistä, mutta jonkin verran vertailua tehdään myös ruotsinkielisiin teksteihin. Suomensuomalaiset ja ruotsinsuomalaiset aineistot eivät ole täysin vertailukelpoisia, koska jälkimmäiset tekstit ovat lyhyitä ja tiivistelmänomaisia. Ruotsinsuomalainen aineisto kuitenkin kattaa kaiken saatavilla olleen tekstimateriaalin, joten vertailua voi pitää perusteltuna. Artikkeli on hyvin kirjoitettu ja osoittaa, että Tolvanen hallitsee myös suomen kielen kieliopillisen analyysin. Aikaisempaa puhutteluun liittyvää tutkimusta käsitellään sekä suomen että ruotsin kielen osalta selkeästi ja riittä- 
vässä määrin. Tulokset osoittavat, että puhuttelua käytetään eniten ruotsinsuomalaisissa teksteissä ja vähiten suomenruotsalaisissa teksteissä. Tuloksista havaitaan myös, että lukijaan viitataan pääasiassa yksikön 2. persoonan muodoilla, mitä voidaan pitää tässä kontekstissa neutraalina puhuttelun tapana. Puhuttelun tulkinnasta on artikkelissa kiinnostavia pohdintoja: eri lukijat voivat esimerkiksi iästä riippuen tulkita samat muodot eri tavoin. Se, mikä toiselle tuo kirjoittajan lähemmäksi lukijaa, voi olla toiselle alentuvaa puhuttelua. Toinen mielenkiintoinen havainto on, että puhutteluun liitetään pääosin neutraaleja tai myönteisiä merkityksiä. Sen sijaan arkaluontoiset asiat (rahaasiat, kuolema tai sairaudet) sekä rajoitukset ja kiellot ilmaistaan epäsuorasti etäkohteliaisuuden keinoin. Näin havaitaan, että tekstin sävy ja siitä lukijalle syntyvä vaikutelma muodostuvat kielellisten valintojen kokonaisuudesta ja suhteesta toisiinsa. Tässä kokonaisuudessa puhuttelun tehtävä on tuoda tekstin muutkin merkitykset lähemmäksi lukijaa.

Väitöskirjan viides osatutkimus on julkaistu Folkmålsstudier-lehdessä (Tolvanen 2016b), ja se käsittelee persoonattomia rakenteita. Menetelmällisesti artikkelissa sovelletaan Thompsonin ja Thetelan (1995) kirjoitettujen tekstien vuorovaikutuksen analyysimallia sekä suomen- että ruotsinkielisiin teksteihin. Artikkelissa esitellään käsitteet interaktiivinen aukko (interaktionell lucka) ja interaktiivinen inkongruenssi (interaktionell inkongruens). Niillä tarkoitetaan kielen keinoja, joiden avulla voidaan välttää toiminnan osapuolen ilmaiseminen. Passiivin ja nollapersoonan lisäksi kirjoittaja laskee tällaisiksi keinoiksi myös ruotsin kielen manrakenteen. Analyysin tulokset osoittavat, miten erityyppisiä persoonattomia rakenteita hyödynnetään teksteissä ja minkälainen työnjako niiden välillä on. Persoonattomia rakenteita käytetään aineistossa korostamaan tekstien institutionaalista luonnetta, ilmaisemaan negatiivista kohteliaisuutta sekä tiivistämään ilmaisua. Artikkelissa tarkastellaan koko väitöskirjan aineistoa, ja analyysiä voi pitää onnistuneena erityisesti Thompsonin ja Thetelan käsitteiden soveltamisen osalta.

\section{Kokonaisarvio}

Artikkeliväitöskirjoille tyypilliseen tapaan tutkijana kehittyminen näkyy myös Tolvasen väitöskirjan artikkeleissa: uudemmat ovat tutkimukselliselta otteeltaan vahvempia kuin vanhemmat. Erityisen onnistuneita ovat analyysit, joissa Tolvanen kehittää edelleen systeemisfunktionaalisen kieliopin osallistujarooleihin ja vuorovaikutukseen liittyviä käsitteitä. Myös perinteisempi lukijan puhuttelun analyysi tuottaa mielenkiintoisia tuloksia. Erityisen kiinnostava on yhteenveto-osassa kuvattu kyselytutkimus, jossa on selvitetty eläketekstien tuottamisen konteksteja Suomessa ja Ruotsissa. Kyselyn tulokset osoittavat muun muassa, että kielenhuollon rooli on virastoissa erilainen. Suomen Kelassa tiedottajat kirjoittavat tekstit, joita asiantuntijat kommentoivat, kun taas Ruotsin Eläkevirastossa tekstit ovat asiantuntijoiden tuottamia ja tiedottajien tehtävänä on muokata niitä. Kelalla on myös oma suomen kielen kielenhuoltaja, mutta ruotsin osalta sellaista ei ole kummassakaan virastossa. Eri viranomaisten tekstin tuottamisen käytäntöjen vaikutus lopputulokseen muodostaakin kiinnostavan ja vähän tutkitun jatkotutkimusaiheen.

Tutkimuksen tulokset esitellään yhteenveto-osassa selkeästi ja havainnollisesti. Päätulos ei aiemman tutkimuksen pohjalta ole kovinkaan yllättävä: leksikaalis-kieliopilliset valinnat tukevat Suomessa viranomaisen auktoriteettia tiedon jakajana, kun taas lukija näyttäytyy passiivisena tiedon vastaanottajana. Ruotsissa ollaan epämuodollisempia ja viranomainen esitetään vähemmän autoritäärisenä 
kansalaisen auttajana. Toisaalta molemmissa maissa puhutellaan lukijaa yksikön toisen persoonan muodoilla. Myös Suomessa yksikön toisen persoonan käyttö teitittelyn sijasta on vakiintunut, eli viranomaisten kielenkäyttö on muuttunut vapaampaan suuntaan. Maiden toisen kielen osalta kielen status näkyy viranomaistekstin pituudessa: ruotsinsuomalaiset tekstit ovat lyhyitä, ja samalla sivulla on aina myös ruotsinkielinen versio tekstistä, kun taas suomenruotsalaiset tekstit ovat pääosin täsmällisiä käännöksiä vastaavista suomenkielisistä teksteistä.

Jonkin verran enemmän tilaa olisi voinut antaa teoreettiselle reflektoinnille sekä laajemmalle ja kriittisemmälle tulosten merkityksen pohtimiselle. Kielellisesti Tolvasen ruotsinkielinen teksti on sujuvaa ja myös tyylillisesti helppolukuista. Kokonaisuudessaan väitöskirja muodostaa onnistuneen ja toimivan kokonaisuuden, jossa teoreettinen viitekehys sitoo hyvin yhteen erilaisia osatutkimuksia.

\section{Merja Koskela etunimi.sukunimi@uwasa.fi}

\section{Lähteet}

Halliday, Michael A. K. 1998: Things and relations. Regrammaticising experience as technical knowledge. - J. R. Martin \& Robert Veel (toim.), Reading science. Critical and functional perspectives on discourses of science s. 185-235. London: Routledge.

Halliday, Michael A. K., - MatthiesSen, Christian M. A. M. 2004: An introduction to functional grammar. Kolmas, uudistettu laitos. London: Arnold.

Lassus, Jannika 2006: Är du Ägare eller Gynnad? En analys av deltagare i myn- dighetsbroschyrer. - Per Ledin, Lena Lind Palicki, Christina Melin, Gunvor Nilsson, Karolina Wirdenäs, \& Håkan Åbrink (toim.), Svenskans beskrivning 28. Förhandlingar vid Tjugoåttonde sammankomsten för svenskans beskrivning. Örebro den 14-15 oktober 2005 s. 169-178. Örebro: Örebro universitet.

Reuter, Mikael 2006: Översättning och språkriktighet. Version 2006. Helsingfors: Svensk Språktjänst AB.

Thompson, Geoff - Thetela, Puleng 1995: The sound of one hand clapping. The management of interaction in written discourse. - Text 15 s. 103-127.

Tolvanen, Evelinna 2013: Informerande myndighetstexter på webben i ett kontrastivt perspektiv. - Maria Eronen \& Marinella Rodi-Risberg (toim.), Haasteena näkökulma. Perspektivet som utmaning. Point of view as challenge. Perspektivität als Herausforderung. VAKKI-symposiumi XXXIII 7.-8.2.2013 s. 362-373. VAKKI Publications 2. Vaasa: Vaasan yliopisto.

_ 2014a: Auktoritet i finlandssvenska och sverigesvenska myndighetstexter. En studie av lexikogrammatiska val och ergativa roller. - Språk och stil. Tidskrift för svensk språkforskning 24 s. 169-199.

_ 2014b: Komplexa nominalfraser i finlandssvenska myndighetstexter. Folkmålsstudier 52 s. 214-226.

_ 2016a: Lukijan suora puhuttelu suomalaisissa ja ruotsinsuomalaisissa viranomaisteksteissä. - Virittäjä 120 s. 5-29. 2016b: Någon särskild ansökan behöver inte göras. Opersonliga konstruktioner i myndighetstexter på svenska och finska i Finland och Sverige. - Folkmålsstudier 54 s. 115-141. 